OPEN ACCESS

Edited by:

Dejian Huang,

National University of Singapore,

Singapore

Reviewed by:

Muhammad Safder

University of Karachi, Pakistan

Marcin Szymanski,

Poznan University of Medical

Sciences, Poland

*Correspondence:

Andrea Buettner,

Erlangen, Germany

andrea.buettner@fau.de

Specialty section:

This article was submitted to

Food Chemistry,

a section of the journal

Frontiers in Chemistry

Received: 31 July 2015 Accepted: 14 September 2015

Published: 06 October 2015

Citation:

Elsharif SA, Banerjee A and Buettner A (2015) Structure-odor relationships of linalool, linalyl acetate and their corresponding oxygenated derivatives. Front. Chem. 3:57.

doi: 10.3389/fchem.2015.00057

\section{Structure-odor relationships of linalool, linalyl acetate and their corresponding oxygenated derivatives}

\author{
Shaimaa A. Elsharif ${ }^{1}$, Ashutosh Banerjee ${ }^{2}$ and Andrea Buettner ${ }^{1,3 *}$ \\ ${ }^{1}$ Department of Chemistry and Pharmacy, Food Chemistry, Emil Fischer Center, Friedrich-Alexander-Universität \\ Erlangen-Nürnberg, Erlangen, Germany, ${ }^{2}$ Department of Chemistry and Pharmacy, Pharmaceutical Chemistry, Emil Fischer \\ Center, Friedrich-Alexander-Universität Erlangen-Nürnberg, Erlangen, Germany, ${ }^{3}$ Department of Sensory Analytics, \\ Fraunhofer Institute for Process Engineering and Packaging, Freising, Germany
}

Linalool $\mathbf{1}$ is an odorant that is commonly perceived as having a pleasant odor, but is also known to elicit physiological effects such as inducing calmness and enhancing sleep. However, no comprehensive studies are at hand to show which structural features are responsible for these prominent effects. Therefore, a total of six oxygenated derivatives were synthesized from both $\mathbf{1}$ and linalyl acetate $\mathbf{2}$, and were tested for their odor qualities and relative odor thresholds (OTs) in air. Linalool was found to be the most potent odorant among the investigated compounds, with an average OT of $3.2 \mathrm{ng} / \mathrm{L}$, while the 8-hydroxylinalool derivative was the least odorous compound with an OT of $160 \mathrm{ng} / \mathrm{L}$; 8-carboxylinalool was found to be odorless. The odorant 8-oxolinalyl acetate, which has very similar odor properties to linalool, was the most potent odorant besides linalool, exhibiting an OT of $5.9 \mathrm{ng} / \mathrm{L}$. By comparison, 8-carboxylinalyl acetate had a similar OT (6.1 ng/L) as its corresponding 8-oxo derivative but exhibited divergent odor properties (fatty, greasy, musty). Overall, oxygenation on carbon 8 had a substantial effect on the aroma profiles of structural derivatives of linalool and linalyl acetate.

Keywords: Linalool, linalyl acetate, gas chromatography-olfactometry, odor threshold in air, 8-oxolinalyl acetate, 8-carboxylinalyl acetate, odor qualities, retention index

\section{Introduction}

In folk medicines as well as aroma therapy, essential oils and fragrance compounds are being used as therapeutic agents for relieving pain, anxiety reduction and energy enhancement (Lahlou, 2004; Kako et al., 2008; Kiecolt-Glaser et al., 2008). Among them, due to their high volatility, the acyclic monoterpenes are a valuable class of compounds useful for the flavor and fragrance industries (King and Dickinson, 2003). One of the most important acyclic monoterpene substances is linalool $\mathbf{1}$ which represents about $70 \%$ of the terpenoids of floral scents (Stashenko and Martinez, 2008). In perfumery, linalool is a commonly used fragrant ingredient being a component of many perfumes top notes and being found in $60-90 \%$ of cosmetic products (Cal and Krzyzaniak, 2006). Its odor is described in literature as floral, citric, fresh and sweet (d'Acampora Zellner et al., 2007). It is also added to household cleaning agents, furniture care products, waxes, as well as to processed food and beverages, as a fragrance and flavor agent. Linalool is found in the essential oils of over 200 plant species, belonging to different families (Stashenko and Martinez, 2008). For example, linalool 

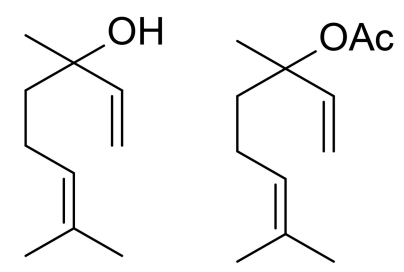

\section{Linalool 1 Linalyl acetate 2}

FIGURE 1 | Lavender oil main constituents.

and its ester form, linalyl acetate 2, are the lavender oil main constituents (Figure 1; Buchbauer et al., 1991). The odor of linalyl acetate is described as floral, sweet and citric, and additionally as minty and slightly caraway-like (d'Acampora Zellner et al., 2007).

Lavender oils are widely used to enhance sleep. Thereby, it has been demonstrated that lavender aromatics can improve sleep in the elderly (Hudson, 1996) and infants (Field et al., 2008). Furthermore, exposure to lavender odors during sleep results in increased duration of deep slow-wave stage sleep (Goel et al., 2005). A closely related therapeutic effect is anxiety reduction, having also been reported for lavender essential oil usage (Tasev et al., 1969). In view of this, linalool has been demonstrated to not only activate olfactory receptors but also to modulate ion channel receptor potentials such as the transient receptor potential channels (TRP) and to potentiate $\gamma$-aminobutanoic acid receptor $\mathrm{A}\left(\mathrm{GABA}_{\mathrm{A}}\right)$-receptor response in the central nervous system (Kessler et al., 2012, 2014); the latter receptor system has been shown to be strongly involved in sedative, anxiolytic and calming processes. TRP channels, on the other hand, are involved in numerous physiological conditions and diseases, and their potential modulation by aroma compounds such as linalool is discussed comprehensively in Friedland and Harteneck (2015). Based on these observations there is a general understanding that linalool plays a valid role in the calming response in humans. However, metabolic side products of linalool, both in plants as well as animals or humans have not been regarded comprehensively in view of either smell or other physiological effects. For gaining deeper insights into the metabolic origin and further fate of linalool and its derivatives, studies were carried out to investigate the metabolism of these substances both in plants (Luan et al., 2006) and animals (Chadha and Madyastha, 1984). Experimental studies on rats using ${ }^{14} \mathrm{C}$-labeled linalool showed that it is rapidly absorbed from the intestinal tract after oral administration. The major part of linalool is metabolized by the liver to polar compounds which are mainly excreted in urine as free form or conjugates; only minor amounts are excreted via the feces. Allylic oxidation becomes an important pathway upon repeated administration, being mediated by the cytochrome P-450 system. 8-Hydroxylinalool and 8-carboxylinalool were detected as major metabolites after 20 days administration of linalool in rats. A minor part undergoes partial ring closure to $\alpha$-terpineol, with the generation of small amounts of geraniol and nerol. These metabolites are also excreted in urine as free forms or conjugates. Products of linalool reduction (dihydro-, tetrahydrolinalool) were also identified in rodent urine (Aprotosoaie et al., 2014). A significant proportion of orally administered linalool follows intermediary metabolic pathways as shown in Scheme 1 (scheme modified from Aprotosoaie et al., 2014).

8-Hydroxylinalool was not only found as a metabolite in mammalian species, but also as an oxidation product isolated from the grape berry mesocarp after linalool was applied to it (Luan et al., 2006). 8-Carboxylinalool was found to be among the constituents of the fruits of Euterpe oleracea (Chin et al., 2008) and the flower of Albizia julibrissin (Yahagi et al., 2012). Linalyl acetate metabolism was also studied in Pseudomonas incognita (Renganathan and Madyastha, 1983), where it was shown that the C-8-methyl moiety is subjected to selective oxidation, giving 8-hydroxylinalyl acetate which is then oxidized to 8-oxo and 8carboxylinalyl acetate, respectively. Apart from that, 8-oxolinalyl acetate was first isolated from lavandin oil and hence reported as a constituent of a natural product (Mookherjee and Trenkle, 1973). 8 -Carboxylinalyl acetate was found in trace amounts $(<0.01 \%)$ in Jabara (Citrus jabara Hort ex. Tanaka) peel extract (Mookherjee and Trenkle, 1973; Table 1).

Therefore, we conclude that the carbonyl, the hydroxyl and the carboxylic acid functional groups in $\alpha$-position to the double bond are very common in nature. These metabolites have been previously synthesized as regio-selectively deuterated compounds for the investigation of their bioconversion into lilac during an in vivo feeding experiment to Syringa vulgaris L., Oleaceae, to study the metabolic pathway of linalool and its derivatives (Kreck et al., 2003). Non-deuterated derivatives were used as reference substances for elucidation of compounds in essential oils isolated from plants to reveal their structural and organoleptic properties (Van Dort et al., 1993). However, the latter study does not contain any explanation of accurate methods of smell determination, nor discuss any further potential physiological impact on humans. Accordingly, neither the odor qualities and odor thresholds of these substances are investigated systematically, nor is it clear what makes linalool so unique for its odor but also other physiological effects.

Based on these considerations we synthesized, starting from 1 and 2, previously reported metabolites and hypothetical derivatives of linalool and its related ester in order to determine their respective odor qualities and thresholds. We thereby aimed at elucidating if linalool itself represents the most potent and characteristic member of this substance group or if any other potent compounds are promising natural physiological chemostimuli in humans. Finally, the aim was to provide a substance library that should further aid in future analytical studies, with compiled data on Retention Indices (RI-values) as well as mass spectrometric and nuclear magnetic resonance data.

\section{Materials and Methods}

\section{Chemicals}

The following chemicals were purchased from the suppliers given in parentheses: linalool, linalyl acetate, selenium dioxide, sodium borohydride, methanol, methanol anhydrous, ethanol, dioxane, 


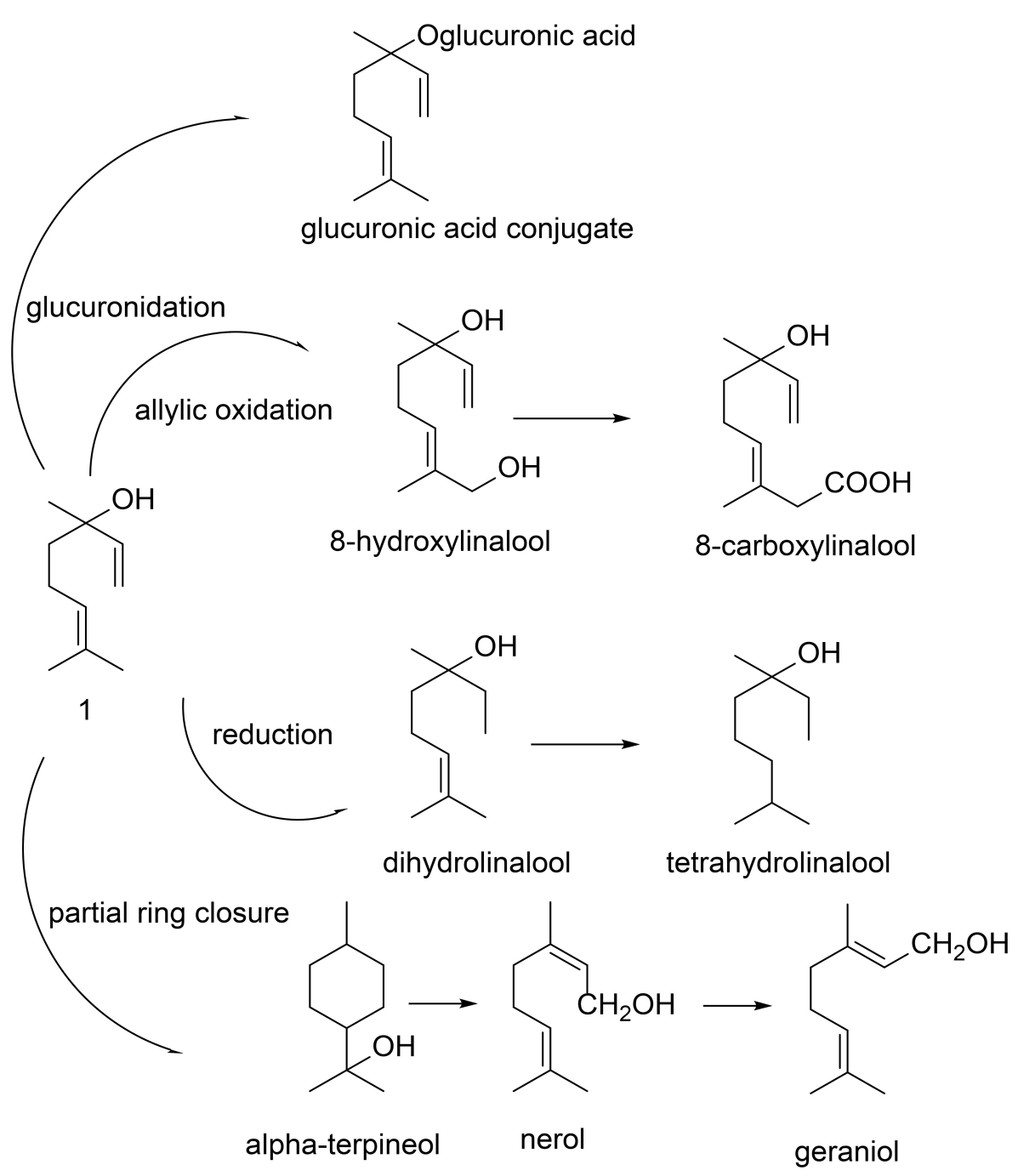

SCHEME 1 | Main linalool metabolic pathway in mammals (scheme modified from Aprotosoaie et al., 2014).

tert-butyl alcohol, 2-methyl-2-butene, petroleum ether, sodium chlorite, sodium dihydrogen phosphate, ethyl acetate, hexane, magnesium sulfate (Aldrich, Steinheim, Germany), diethyl ether (Fisher Scientific, Loughborough).

\section{General Methods}

All reactions requiring anhydrous conditions were carried out under nitrogen and the solvents were dried before use to remove moisture using appropriate drying solvents. All reactions were monitored by TLC using Kieselgel $60 \quad \mathrm{~F}_{254}$ plates. Visualization of the reaction components was achieved using UV fluorescence $(254 \mathrm{~nm})$ and $\mathrm{KMnO}_{4}$ stain. Column chromatography was carried out over silica gel 60 . The yields reported are after purification. ${ }^{1} \mathrm{H}$ and ${ }^{13} \mathrm{C}$ NMR spectra were recorded in deuterated solvents and chemical shifts $(\delta)$ are quoted in parts per million (ppm) calibrated to TMS $\left({ }^{1} \mathrm{H}\right.$ and $\left.{ }^{13} \mathrm{C}\right)$. Coupling constants $(J)$ were measured in Hertz $(\mathrm{Hz})$. The following abbreviations are used to describe multiplicities: $\mathrm{s}=$ singlet, $\mathrm{d}=$ doublet, $\mathrm{t}=$ triplet, $\mathrm{q}=$ quartet, $\mathrm{b}=$ broad, $\mathrm{m}=$ multiplet. The identity of all intermediates and synthetic products was determined by MS/EI.

\section{Nuclear Magnetic Resonance (NMR) Spectra}

${ }^{1} \mathrm{H}$ and ${ }^{13} \mathrm{C}$ NMR spectra were recorded in $\mathrm{CDCl}_{3}$ on an Avance 360 spectrometer, $360 \mathrm{MHz}$, and Avance 600, $600 \mathrm{MHz}$ (Bruker Biospin, Rheinstetten, Germany) at room temperature operated at 360 or $600 \mathrm{MHz}\left({ }^{1} \mathrm{H}\right)$ and 90 or $150 \mathrm{MHz}\left({ }^{13} \mathrm{C}\right)$, with tetramethylsilane (TMS) as internal standard.

\section{Gas chromatography-olfactometry (GC/O) and GC-electron Impact-mass Spectrometry (GC-EI-MS)}

GC-O analyses were performed with a Trace GC Ultra (Thermo Fisher Scientific GmbH, Dreieich, Germany) by using the following capillaries: FFAP $(30 \mathrm{~m} \times 0.32 \mathrm{~mm}$ fused silica capillary, free fatty acid phase FFAP, $0.25 \mu \mathrm{m}$; Chrompack, 
TABLE 1 | Retention indices and occurrence of linalool and its derivatives.

\begin{tabular}{|c|c|c|c|c|}
\hline \multirow[t]{2}{*}{ Entry } & \multirow[t]{2}{*}{ Odorant } & \multicolumn{2}{|c|}{$\mathbf{R} \mathbf{I}^{\mathbf{a}}$} & \multirow[t]{2}{*}{ Previously identified in } \\
\hline & & DB5 & FFAP & \\
\hline 1 & Linalool & 1108 & 1550 & $\begin{array}{l}\text { Some examples: Wood of Aniba rosaeodora Ducke, Lauraceae }{ }^{\mathrm{b}} \text {, Flowering tops of Lavandula officinalis, } L \text {. } \\
\text { angustifolia Mill., Lamiaceae }{ }^{\mathrm{c}} \text {, Coriandrum sativum L., Apiaceae }{ }^{\mathrm{d}} \text {, Flowers of Citrus sinensis Osbeck, } \\
\text { Rutaceae }^{\mathrm{e}}\end{array}$ \\
\hline 2 & Linalyl acetate & 1264 & 1563 & $\begin{array}{l}\text { Lavandula angustifolia Miller }{ }^{f}, \text { Micromeria kerneri and Micromeria juliana Lamiaceae }{ }^{g} \text {, Origanum vulgare } \\
\text { Lamiaceae }^{\text {h. }}\end{array}$ \\
\hline 3 & 8-Oxolinalool & 1350 & 2150 & Narcissus trevithian and Narcissus geranium Amaryllidaceae ${ }^{\mathrm{i}}$ \\
\hline 4 & 8-Oxolinalyl acetate & 1490 & 2133 & Lavandin oilj \\
\hline 5 & 8-Hydroxylinalyl acetate & 1530 & 2333 & As a linalyl acetate metabolite by pseudomonas incognitak \\
\hline 6 & 8-Hydroxylinalool & 1380 & 2320 & $\begin{array}{l}\text { Chamaecyparis Obtuse }{ }^{l} \text {, Vitis vinifera (muscat grape skins) }{ }^{m} \text {, Pluchea indica }{ }^{n} \text {, As a linalool metabolite in urine } \\
\text { of rats }^{\circ} \text {, and as a linalool oxidation product in grape berry mesocarp }{ }^{p} \text {. }\end{array}$ \\
\hline 7 & 8-Carboxylinalool & 1540 & 1929 & Fruits of Euterpe oleraceaq, flower of Albizia julibrissin ${ }^{r}$. \\
\hline 8 & 8-Carboxylinalyl acetate & 1650 & 1957 & Trace amounts in Jabara (Citrus jabara Hort ex. Tanaka)s \\
\hline
\end{tabular}

a retention indices were determined as described by Van Den Dool and Kratz (1963).

${ }^{b}$ Chantraine et al. (2009).

c Ozek et al. (2010).

dTsagkli et al. (2012).

e Miguel et al. (2008).

${ }^{f}$ Buchbauer et al. (1991).

gKremer et al. (2014).

${ }^{h}$ Andi et al. (2012).

iVan Dort et al. (1993).

jMookherjee and Trenkle (1973).

${ }^{k}$ Renganathan and Madyastha (1983).

'Matsubara et al. (1990).

m Strauss et al. (1988).

nUchiyama et al. (1989).

- Chadha and Madyastha (1984).

PLuan et al. (2006).

aChin et al. (2008).

rYahagi et al. (2012).

sOmori et al. (2011).

Mühlheim, Germany) and DB5 (30 $\mathrm{m} \times 0.32 \mathrm{~mm}$ fused silica capillary DB-5, $0.25 \mu \mathrm{m}$; J\&W Scientific, Fisons Instruments). The helium carrier gas flow was set at $2.0 \mathrm{~mL} / \mathrm{min}$. The compounds eluting at the end of the capillaries were split with a Y-splitter (J\&W Scientific; ratio 1:1 v/v) and transferred via two deactivated capillaries $(0.5 \mathrm{~m} \times 0.2 \mathrm{~mm}$, J \&W Scientific) to a flame ionization detector and a heated sniffing port (temperature: $250^{\circ} \mathrm{C}$ ). The samples were applied onto the capillary using a cold-on-column injector at $40^{\circ} \mathrm{C}$. After $2 \mathrm{~min}$, the oven was heated at a rate of $15^{\circ} \mathrm{C} / \mathrm{min}$ to $240^{\circ} \mathrm{C}$ and held for $2 \mathrm{~min}$. GC-EI MS analyses were performed with an Agilent MSD 5975C (Agilent Technologies, Waldbronn, Germany) and a Thermo ITQ 900 (Thermo Fisher Scientific, Dreieich, Germany) with the capillaries described above. Mass spectra in the electron impact mode (EI-MS) were generated at $70 \mathrm{eV}$.

\section{Retention Indices (RI)}

Retention indices (Table 1) were determined by the method previously described by Van Den Dool and Kratz (1963).

\section{Evaluation of Odor Quality}

The odor qualities were determined during GC-O evaluation by the aid of panelists who were trained volunteers from the University of Erlangen (Erlangen, Germany), exhibiting no known illness at the time of examination and with audited olfactory function. In preceding weekly training sessions the assessors were trained for at least half a year in recognizing orthonasally about 90 selected known odorants at different concentrations according to their odor qualities and in naming these according to an in-house developed flavor language.

\section{Determination of Odor Thresholds}

Odor thresholds were determined in air following the procedure described by Czerny et al. (2011) using (E)-dec-2-enal as an internal odor standard. This procedure offers the advantage that compounds that might be present as odor-active impurities in the reference compound are separated from the target odorants during the chromatographic separation step. In consequence, an influence of such components on the results is avoided. Also, odor thresholds can be compared to each other on an absolute basis without interference with any matrix system as would be the case e.g., when determining odor thresholds in water. The detection odor thresholds of the panel were calculated as the geometric mean of the individual thresholds according to Czerny et al. (2008). 


\section{Synthesis, General Procedures General Procedure 1(GP1)}

Generally, the method of Wakayama et al. (1973) was used (Scheme 2). Compounds $\mathbf{1}$ and $\mathbf{2}$ and selenium dioxide (1 eq.) were dissolved in dioxane/ethanol 9:1 (v/v), and the solution was heated at $80^{\circ} \mathrm{C}$ for $5 \mathrm{~h}$. After removal of selenium deposit by filtration, the solvent was removed under reduced pressure using a rotary evaporator. The residue was treated with diethyl ether/petroleum ether 1:1 (v/v), and after removal of the solvent, the residue was purified by flash chromatography on silica gel 60 (Merck), with a mobile phase of petroleum ether/diethyl ether, affording the crude compounds 3 and $\mathbf{4}$, respectively.

\section{(E)-3,7-dimethyl-8-oxoocta-1,6-dien-3-ol (3), 8-oxolinalool}

Following GP1, from 1 (4.8 g, $31.1 \mathrm{mmol})$ and selenium dioxide (3.4 g, $30.4 \mathrm{mmol})$ in $30 \mathrm{ml}$ dioxane/ethanol 9:1 (v/v), compound 3 was prepared. Flash chromatographic purification with petroleum ether/diethyl ether 1:4 (v/v) yielded $1.4 \mathrm{~g}(29 \%)$ of 3 as orange oil. ${ }^{1} \mathrm{H}$ NMR ( $600 \mathrm{MHz}$, CHLOROFORM- $d$ ) $\delta \mathrm{ppm}$ $9.38(1 \mathrm{H}, \mathrm{s}), 6.42-6.56(1 \mathrm{H}, \mathrm{m}), 5.92(1 \mathrm{H}, \mathrm{dd}, J=17.26$, $10.67 \mathrm{~Hz}), 5.25(1 \mathrm{H}, \mathrm{dd}, J=17.26,0.91 \mathrm{~Hz}), 5.11(1 \mathrm{H}, \mathrm{dd}, J=$ 10.90, 0.91 Hz), 2.35-2.45 (2 H, m), $1.74(3 \mathrm{H}, \mathrm{s}), 1.61-1.71(2$ $\mathrm{H}, \mathrm{m}), 1.31-1.35$ (3 H, m) ${ }^{13} \mathrm{C}$ NMR (91 MHz, CHLOROFORMd) $\delta$ ppm 195.2., 154.6, 144.3, 139.2, 112.4, 72.9, 40.3, 28.1, 23.8, 9.1.MS (EI) $m / z$ (\%) (rel.int.): $168\left[\mathrm{M}^{+}\right](1), 98(15), 87(27)$, 82(24), 71(100), 55(33), 43(58), 41(23).

\section{(E)-3,7-dimethyl-8-oxoocta-1,6-dien-3-yl-acetate (4), 8-oxolinalyl Acetate}

Following GP1, from 2 (5 g, $25 \mathrm{mmol}$ ) and selenium dioxide $(2.7$ g, $25 \mathrm{mmol}$ ) in $15 \mathrm{ml}$ dioxane/ethanol 9:1 (v/v), compound 4 was prepared. Flash chromatographic purification with petroleum ether/diethyl ether 3:2(v/v) yielded $1.4 \mathrm{~g}(29 \%)$ of 4 as orange oil. ${ }^{1} \mathrm{H}$ NMR (600 MHz, CHLOROFORM-d) $\delta$ ppm $9.39(1 \mathrm{H}, \mathrm{s})$, 6.44-6.50 (1 H, m), $5.96(1 \mathrm{H}, \mathrm{dd}, J=17.56,11.14 \mathrm{~Hz}), 5.15-5.26$ $(2 \mathrm{H}, \mathrm{m}), 2.37(2 \mathrm{H}, \mathrm{q}, J=7.93 \mathrm{~Hz}), 2.06-2.12(1 \mathrm{H}, \mathrm{m}), 2.02$ (3 $\mathrm{H}, \mathrm{s}), 1.87-1.95(1 \mathrm{H}, \mathrm{m}), 1.74(3 \mathrm{H}, \mathrm{s}), 1.59(3 \mathrm{H}, \mathrm{s}) .{ }^{13} \mathrm{C} \mathrm{NMR}$ (151 MHz, CHLOROFORM-d) $\delta$ ppm 195.1, 169.9, 153.7, 141.1, $139.5,113.8,82.3,38.1,23.79,23.79,22.1,9.12$. MS (EI) $\mathrm{m} / z(\%)$ (rel.int.): $210\left[\mathrm{M}^{+}\right]$(1), 150(18.38), 135(14), 121(19), 107(18.05), 93(26), 82(41), 71(46), 55(29), 43(100).

\section{Procedure 2}

(E)-8-hydroxy-3,7-dimethylocta-1,6-dien-3-yl-acetate (5), 8-hydroxylinalyl Acetate

Compound 4 (800 mg, $3.81 \mathrm{mmol}$ ) was dissolved in dry methanol $(40 \mathrm{ml})$ and sodium borohydride $\left(\mathrm{NaBH}_{4} ; 1.8 \mathrm{~g}, 4.72 \mathrm{mmol}\right)$ was added (Liu et al., 2003; Scheme 2). The solution was allowed to stir at $-10^{\circ} \mathrm{C}$. After $1 \mathrm{~h}$, water was added and the reaction mixture was extracted with dichloromethane (DCM). The organic layer was dried over sodium sulfate. After removal of the solvent, the residue was subjected to flash chromatography eluted with petroleum ether/diethyl ether 2:3 (v/v) and yielded $626 \mathrm{mg}(77 \%)$ of 5 as light yellow oil. ${ }^{1} \mathrm{H}$ NMR $(360 \mathrm{MHz}$, CHLOROFORM-d) $\delta$ ppm $5.97(1 \mathrm{H}, \mathrm{dd}, J=17.48,10.90 \mathrm{~Hz})$,

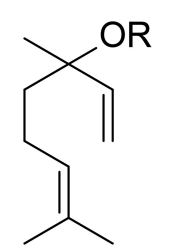

\section{$\mathrm{SeO}_{2} /$ dioxane}<smiles>[CH2-]C</smiles>

(1)<smiles>[R]OC(C)(C=C)CCC=C(C)C=O</smiles>

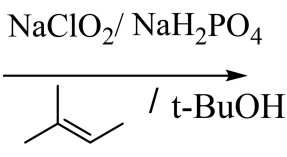

(4)<smiles>[R]OC(C)(C=C)CCC=C(C)C(=O)O</smiles>

$1: \mathrm{R}=\mathrm{H}$ $2: R=A c$
$3: \mathrm{R}=\mathrm{H}$ $4: R=A c$
$7: \mathrm{R}=\mathrm{H}$ $8: R=A c$<smiles>C=CC(C)(CCC=C(C)C=O)OC(C)=O</smiles><smiles>OC(O)c1ccccc1</smiles><smiles>C=CC(C)(CCC=C(C)CO)OC(C)=O</smiles>

5<smiles>C=CC(C)(O)CC/C=C(\C)CO</smiles>

6

SCHEME 2 | Synthetic pathways for the synthesis of linalool and linalyl acetate oxygenated derivatives following procedures 1-4. 
5.36-5.43 (1 H, m), $5.15(2 \mathrm{H}, \mathrm{dd}, J=17.48,11.13 \mathrm{~Hz}), 3.99$ $(2 \mathrm{H}, \mathrm{d}, J=5.45 \mathrm{~Hz}), 2.03-2.09(2 \mathrm{H}, \mathrm{m}), 2.01(3 \mathrm{H}, \mathrm{s})$, 1.75-1.96 (2 H, m), $1.66(3 \mathrm{H}, \mathrm{s}), 1.55(3 \mathrm{H}, \mathrm{s}) .{ }^{13} \mathrm{C} \mathrm{NMR}(91$ $\mathrm{MHz}$, CHLOROFORM-d) $\delta$ ppm 169.9, 141.7, 135.2, 125.4, 113.3, 82.8, 68.8, 39.4, 23.7, 22.2, 21.9, 13.6. MS (EI) $\mathrm{m} / z$ (\%) (rel.int.): $211\left[\mathrm{M}^{+}-1\right](1), 134(7), 119(27), 93(46), 79(35), 67(30), 55(24)$, 43(100).

\section{Procedure 3}

(E)-2, 6-dimethylocta-2,7-diene-1,6-diol (6), 8-hydroxylinalool

Compound 5 (311 mg, $1.46 \mathrm{mmol}$ ) was dissolved in methanol $(50 \mathrm{ml})$ and $0.1 \mathrm{M} \mathrm{KOH}(50 \mathrm{ml})$ was added (Hasegawa, 1983; Scheme 2). The reaction mixture was allowed to stir at $60^{\circ} \mathrm{C}$. After $4 \mathrm{~h}$, the solution was extracted with DCM and the organic layer was dried over sodium sulfate. The solvent was removed under reduced pressure and flash chromatographic purification with petroleum ether/diethyl ether 1:4 (v/v) yielded $203.8 \mathrm{mg}(82 \%)$ of 6 as transparent oil. ${ }^{1} \mathrm{H}$ NMR $(600 \mathrm{MHz}$, CHLOROFORM-d) $\delta$ ppm $5.93(1 \mathrm{H}$, dd, $J=17.19,10.76 \mathrm{~Hz})$, 5.41-5.45 (1 H, m), $5.16(2 \mathrm{H}, \mathrm{dd}, J=17.75,10.95 \mathrm{~Hz}), 4.00(2$ $\mathrm{H}, \mathrm{s}), 2.03-2.16(2 \mathrm{H}, \mathrm{m}), 1.68$ (3 H, s), 1.59-1.65 (2 H, m), 1.31 (3 H, s). ${ }^{13} \mathrm{C}$ NMR (151 MHz, CHLOROFORM-d) $\delta$ ppm 144.9, $135.0,125.9,111.8,73.3,68.9,41.7,27.9,22.3,13.6$. MS (EI) $\mathrm{m} / z$ (\%) (rel.int.): $170\left[\mathrm{M}^{+}\right]$(1), 150(16), 135(13), 131(18), 107(17), 95(25), 82(39), 71(44), 55(28), 43(100).

\section{General Procedure 4 (GP4)}

Pinnick oxidation was used for the following syntheses (Pinnick et al., 1981; Scheme 2). The aldehydes 3 and $\mathbf{4}$ were dissolved in $25 \mathrm{ml}$ of tert-butyl alcohol and $6 \mathrm{ml} \mathrm{2-methyl-2-}$ butene. A solution of sodium chlorite (9.2 eq.) and sodium dihydrogenphosphate (6.9 eq.) in $10 \mathrm{ml}$ water was added drop wise over a $10 \mathrm{~min}$ period. The reaction mixture was stirred at room temperature overnight. Volatile components were then removed under vacuum, the residue was dissolved in $30 \mathrm{ml}$ water and this was extracted with two $15 \mathrm{ml}$ portions of hexane. The aqueous layer was acidified to $\mathrm{pH} 3$ with $\mathrm{HCl}$ and extracted with three $20 \mathrm{ml}$ portions of ether. The combined ether layers were washed with $50 \mathrm{ml}$ cold water dried and concentrated to give 7 and $\mathbf{8}$, respectively.

\section{(E)-6-hydroxy-2,6-dimethylocta-2,7-dienoic-acid (7), 8-carboxylinalool}

Following GP4, Compound 3 ( $800 \mathrm{mg}, 4.75 \mathrm{mmol}$ ) was dissolved in $25 \mathrm{ml}$ tert-butyl alcohol and $6 \mathrm{ml} \mathrm{2-methyl-2-butene.} \mathrm{A}$ solution of sodium chlorite $(3.95 \mathrm{gm}, 43.7 \mathrm{mmol})$ and sodium dihydrogenphosphate $(3.93 \mathrm{gm}, 32.7 \mathrm{mmol})$ in $10 \mathrm{ml}$ water was added dropwise over a 10 min period, compound 7 was prepared. Flash chromatographic purification with ethyl acetate/methanol 9.5:0.5 (v/v) yielded $373.7 \mathrm{mg}(42.6 \%)$ of 7 as white solid specks. ${ }^{1} \mathrm{H}$ NMR (600 MHz, CHLOROFORM-d) $\delta$ ppm 6.76-6.94 $(1 \mathrm{H}, \mathrm{m}), 5.89(1 \mathrm{H}, \mathrm{dd}, J=17.37,10.58 \mathrm{~Hz}), 5.22(1 \mathrm{H}, \mathrm{dd}, J=$ $17.37,1.13 \mathrm{~Hz}), 5.08(1 \mathrm{H}, \mathrm{dd}, J=10.76,0.94 \mathrm{~Hz}), 2.14-2.33(2$ $\mathrm{H}, \mathrm{m}), 1.81(3 \mathrm{H}, \mathrm{s}), 1.64(2 \mathrm{H}, \mathrm{m}, J=18.70,10.60 \mathrm{~Hz}), 1.30$ (3 H, s). ${ }^{13} \mathrm{C}$ NMR (151 MHz, CHLOROFORM-d) $\delta$ ppm 172.1, $144.5,144.4,127.1,112.2,72.9,40.4,27.9,23.6,12.0$. MS (EI) $\mathrm{m} / z$
$182\left[\mathrm{M}^{+}-2\right](1), 151(4), 138(7), 121(15), 111(14), 103(16), 95(16)$, 82(11), 71(100), 67(18), 55(24).

\section{(E)-6-acetoxy-2,6-dimethylocta-2,7-dienoic-acid (8), 8-carboxylinalyl Acetate}

Following GP4, compound 4 (0.3 gm, $1.24 \mathrm{mmol})$ was dissolved in $25 \mathrm{ml}$ tert-butyl alcohol and $6 \mathrm{ml} \mathrm{2-methyl-2-butene.} \mathrm{A}$ solution of sodium chlorite $(1.08 \mathrm{gm}, 11.4 \mathrm{mmol})$ and sodium dihydrogenphosphate $(1.05 \mathrm{gm}, 8.55 \mathrm{mmol})$ in $10 \mathrm{ml}$ water was added dropwise over a 10 min period, compound 8 was prepared. Flash chromatographic purification with ethyl acetate/methanol 9.5:0.5 (v/v) yielded $131.8 \mathrm{mg}(47 \%)$ of 8 as light yellow oil. ${ }^{1} \mathrm{H}$ NMR (600 MHz, CHLOROFORM-d) $\delta$ ppm 6.87-6.92 (1 H, m), $5.95(1 \mathrm{H}, \mathrm{dd}, J=17.37,10.95 \mathrm{~Hz}), 5.17(2 \mathrm{H}, \mathrm{dd}, J=17.37$, $10.95 \mathrm{~Hz}), 2.17-2.24(2 \mathrm{H}, \mathrm{m}), 2.02(3 \mathrm{H}, \mathrm{s}), 1.84-2.00(2 \mathrm{H}, \mathrm{m})$, $1.83(3 \mathrm{H}, \mathrm{s}), 1.57(3 \mathrm{H}, \mathrm{s}) .{ }^{13} \mathrm{C}$ NMR (91 MHz, CHLOROFORMd) $\delta$ ppm 173.1, 169.8, 144.1, 141.1, 127.2, 113.5, 82.3, 38.1, 23.6, 23.3, 22.0, 11.8. MS (EI) $m / z 226\left[\mathrm{M}^{+}\right]$(2), 166(15), 148(19), 121(100), 105(84), 91(91), 79(98), 67(89), 55(42).

\section{Results}

Odor qualities for $\mathbf{1}$ and $\mathbf{2}$ and their C-8 oxygenated synthesized derivatives were investigated by trained panelists using GC-O, the obtained attributes are shown in Table 2. It was found that linalool, 8-oxolinalool and 8-hydroxylinalool exert the same or at least closely related odor qualities. Odor attributes named by the panelists were citrus-like, sweet, soapy, and lemon-like, whereas no odor was perceived at the sniffing port in case of 8-carboxylinalool. It is worth mentioning that the latter compound was odorless for all panelists in the concentration levels evaluated, that means at a concentration up to about $200 \mu \mathrm{g} / \mathrm{ml}$.

The odor of linalyl acetate and its derivatives was described as citrus-like, soapy, fatty, and fresh similarly to linalool with the sole exception of 8-carboxylinalyl acetate; the smell of this substance was described as waxy, fatty, musty, rancid, and greasy. Panelists did not mention in any case the attributes citrus-like, soapy, fresh, or lemon-like for the latter compound.

As shown in Table 2, it is worth mentioning that the attributes provided by $60-70 \%$ of the panelists in case of linalool were citrus-like and flowery, whereas soapy was selected by only $37 \%$ of the panel as descriptor. Only one panelist described linalool odor as balsamic. Regarding the 8-oxolinalool odor, all panelists agreed on the attributes fatty and citrus-like, while $25 \%$ of the panel named the attribute soapy. In contrast to the latter two compounds, exhibiting intense odor, 8-hydroxylinalool was perceived by most panelists as low in odor intensity even in a concentration of $390 \mu \mathrm{g} / \mathrm{ml}$ at the sniffing port. About $88 \%$ of the panelists provided the attribute citrus-like for description of the latter compound, while only one panelist perceived the substance as soapy and flowery; unlike for linalool and the 8-oxolinalool, no panelist mentioned fatty as a descriptor for 8-hydroxylinalool.

In view of linalyl acetate, the citrus-like impression was reported by $60 \%$ of the panelists; fatty and soapy were named by $25 \%$ while lemon-like and melissa-like attributes were given by only one panelist. Furthermore, for the 8-oxolinalyl acetate 
TABLE 2 | Odor qualities of all eight panelists (P1 to P8) and median of the odor threshold of all compounds.

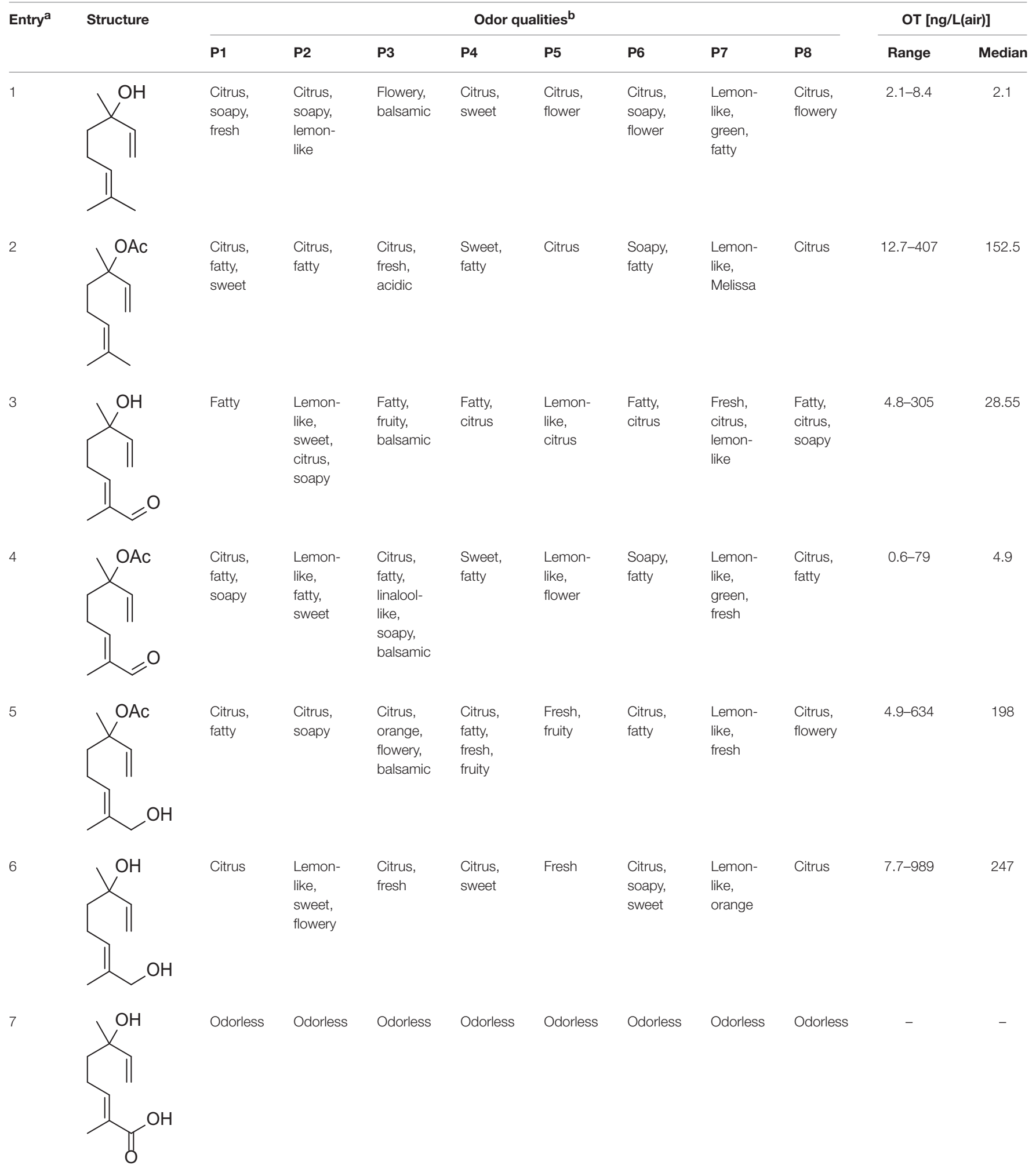


TABLE 2 | Continued

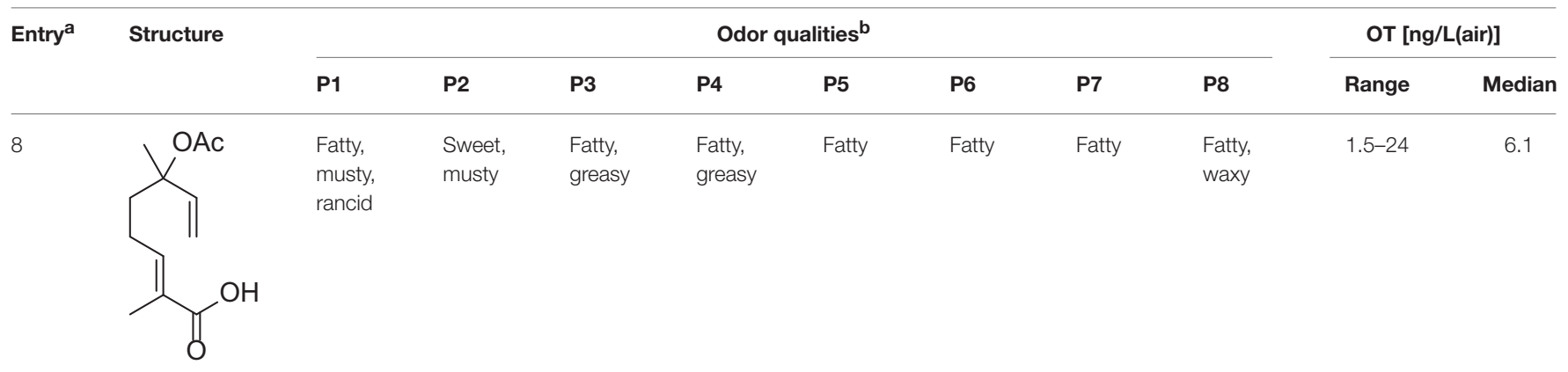

a Numbering refer to Table 1.

${ }^{b}$ Odor qualities as perceived at the sniffing port.

TABLE 3 | Odor thresholds OT (GC-O) of all eight panelists (P1 to P8) of all compounds.

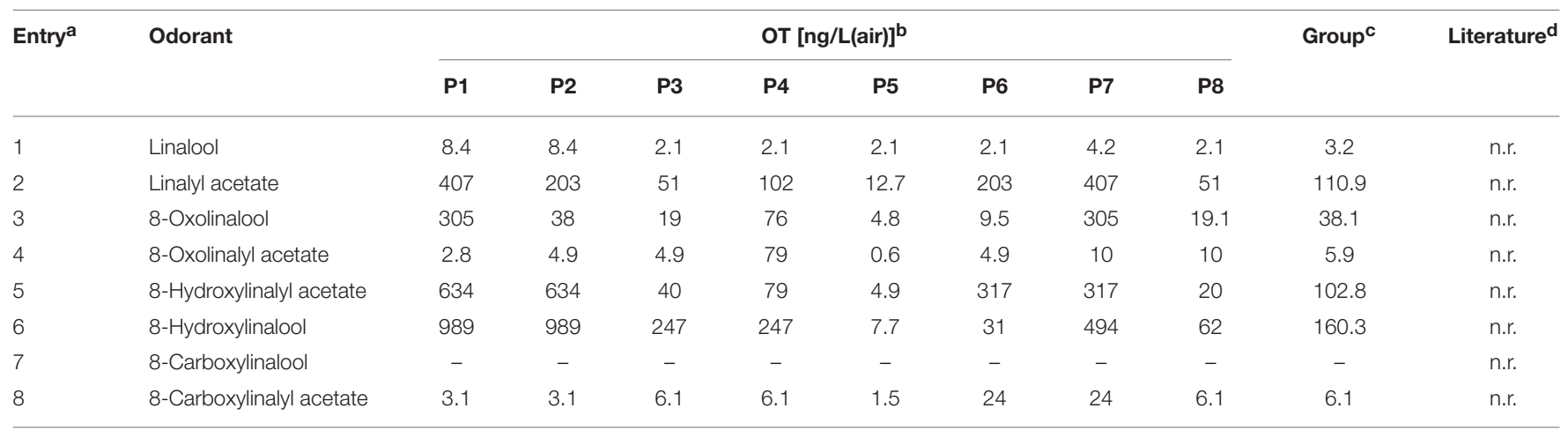

${ }^{a}$ Numbering refer to Table 1.

${ }^{b}$ Odor thresholds in air were determined as described by Ullrich and Grosch (1987).

${ }^{c}$ Group odor threshold was calculated as a geometric mean of the individual thresholds of panelists.

${ }^{d}$ n.r.: Odor threshold was not reported previously.

odor $75 \%$ of the panelists concordantly reported a fatty attribute. About $40 \%$ of the panel further described the odor as lemon-like and citrus-like while only one panelist gave the attribute balsamic and linalool-like. Nevertheless, the main 8-hydroxylinalyl acetate odor attributes were citrus-like, being named by most of the panelists (70-80\%), while fresh and fruity were given by only $20 \%$ of the panel. In contrast to all the previously mentioned odors, the 8-carboxylinalyl acetate smell was described as fatty and additionally as musty, rancid and greasy, but not as soapy.

When evaluating more closely the individual odor threshold results of the panelists, it becomes evident that there are some inter-individual differences that do not only vary from a compound to another but also for a specific substance. Overall, all compounds were perceived with an intense to medium intense odor with the sole exception of 8-hydroxylinalool which imparted weak odor intensity. Thereby, one panelist was exceptionally sensitive to all compounds, recording a threshold value as low as $0.6 \mathrm{ng} / \mathrm{L}$ for the 8 -oxolinalyl acetate, thus, being the lowest threshold value determined within this study (Table 3). In case of linalool, 60\% of the panelists achieved a threshold value of $2.1 \mathrm{ng} / \mathrm{L}$ while in case of the other compounds not more than two panelists concordantly displayed the same odor threshold. To name but one example, the highest threshold was recorded for two panelists for 8-hydroxylinalool with 989 $\mathrm{ng} / \mathrm{L}$; this value is by a factor of 128 higher than the lowest recorded threshold $(7.7 \mathrm{ng} / \mathrm{L})$, in this case again achieved by the sensitive panelist who was discussed before.

When comparing linalool with its oxygen-containing analogs, we found that linalool is the most potent odorant having an odor threshold of $3.2 \mathrm{ng} / \mathrm{L}$ in air (Table 3). All other compounds investigated within this study exhibited an odor threshold of at least a factor of 2 higher than the threshold of linalool. To analyze the secret beyond this intensive odor, it is feasible to have a closer look at the respective substituents on the monoterpene structure.

Addition of an aldehyde group at C- 8 of linalool increases the threshold by a factor of $12(38.1 \mathrm{ng} / \mathrm{L})$. Reduction of this aldehyde to the corresponding alcohol, giving the 8-hydroxylinalool, results in a dramatic decrease in the potency, and a large increase in the threshold value $(160.31 \mathrm{ng} / \mathrm{L})$. Upon oxidation of the 8 -oxolinalool to the corresponding 8-carboxylinalool the odor totally disappears. This means that the C-3 hydroxy group is the only substituent responsible for the linalool high potency and low threshold value, whereas any substituents on C-8, referring to this study (see Figure 2), especially the aldehydic or the alcoholic 


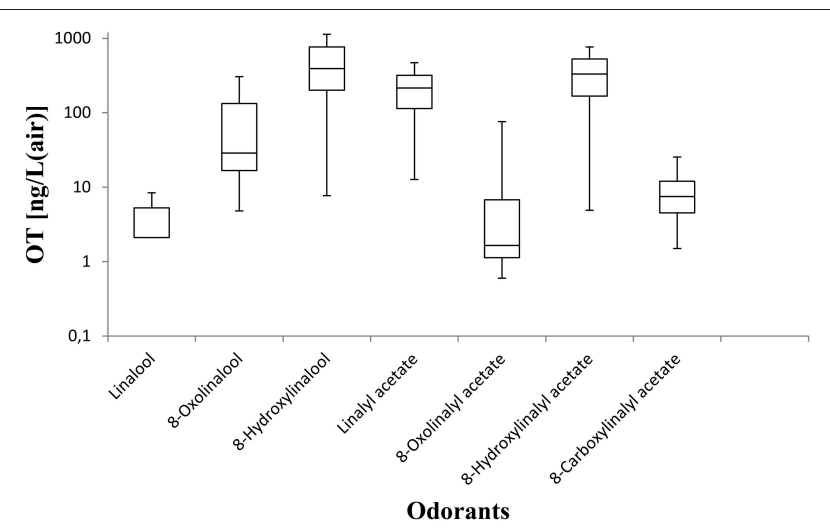

FIGURE 2 | Influence of oxygenated functional groups on the odor threshold of odorants.

functional groups, can still own the same linalool pleasant smell but lack its potency.

For linalyl acetate, the acetate ester of linalool, the odor threshold was determined to be $110.9 \mathrm{ng} / \mathrm{L}$, which is the highest value in relation to linalool despite its sweet, citrus fresh odor. Surprisingly, 8-oxolinalyl acetate, the linalyl acetate-8-aldehyde, was found to be the most potent compound of its corresponding ester derivatives (see Figure 2) with an odor threshold of $5.9 \mathrm{ng} / \mathrm{L}$ which is close to the odor threshold of linalool itself. Its odor quality was also described to be linalool-like and very intense compared to that of its parent substance, the linalyl acetate. Again, the reduction of the C- 8 aldehyde to the respective alcohol gives the 8-hydroxylinalyl acetate with an odor threshold of 102.8 $\mathrm{ng} / \mathrm{L}$ which is comparatively lower than that of linalyl acetate itself. Interestingly, the 8-carboxylinalyl acetate, the oxidation product of the 8-oxolinalyl acetate, retained the odor threshold $(6.1 \mathrm{ng} / \mathrm{L})$ to be nearly the same as for the 8-oxolinalyl acetate (5.9 ng/L) but displayed a complete change in the odor quality to reveal greasy, rancid, and musty attributes rather than the

\section{References}

Andi, S. A., Nazeri, V., Hadian, J., and Zamani, Z. (2012). A comparison of the essential oil chemical composition of Origanum vulgare L. ssp. vulgare collected in its flowering and seed stages from southern region of Chalus. Maj. Ulum-i Baghbani-i Iran 43, 153Persian-159Persian, 155English.

Aprotosoaie, A. C., Hãncianu, M., Costache, I.-I., and Miron, A. (2014). Linalool: a review on a key odorant molecule with valuable biological properties. Flavour Fragr. J. 29, 193-219. doi: 10.1002/ffj.3197

Buchbauer, G., Jirovetz, L., Jäger, W., Dietrich, H., and Plank, C. (1991). Aromatherapy: evidence for sedative effects of the essential oil of lavender after inhalation. Z. Naturforsch. C 46, 1067-1072.

Cal, K., and Krzyzaniak, M. (2006). Stratum corneum absorption and retention of linalool and terpinen-4-ol applied as gel or oily solution in humans. J. Dermatol. Sci. 42, 265-267. doi: 10.1016/j.jdermsci.2006.02.007

Chadha, A., and Madyastha, K. M. (1984). Metabolism of geraniol and linalool in the rat and effects on liver and lung microsomal enzymes. Xenobiotica 14, 365-374. doi: 10.3109/004982584091 51425 citrus-like, soapy, and lemon-like qualities of the 8-oxolinalyl acetate (Table 2).

\section{Conclusion}

From the previous results, one can deduce first insights into structure-odor relationships for the investigated linalool derivatives. Amongst others, the presence of a hydroxy group at C-3 in linalool is the main contributor to both odor quality and potency of all mentioned compounds in this study; thereby, the C-8 position does not contain any functionality in case of linalool. On the contrary, the acetate derivative of this hydroxy group, linalyl acetate, displayed low odor potency. However, we could show that this is compensated by C- 8 oxidation yielding 8 -oxolinalyl acetate and the 8-carboxylinalyl acetate with low thresholds that are in a comparable range as the threshold of linalool but eliciting different odor attributes. On the other hand we could show that the reduced moiety at the C-8 oxidation products yielding the corresponding hydroxy function, does not positively contribute to odor potency, irrespective of whether the C-3 bares a hydroxy or an ester function; this structural modification resulted in the highest odor thresholds determined within this study. To sum up, it can be concluded that in view of the investigated substances predominantly the C-3 substitution with a hydroxy group, a relatively non-voluminous and polar ligand, is important for high odor potency and the characteristic smell properties that are related to linalool. If this hydroxy group is esterified, then C-8 substitution with either an aldehyde or a carboxyl group is crucial to maintain the odor threshold, albeit, thereby losing the specific odor character. Any other structural changes investigated within this study led to either drastic decrease in the potency or even total odor loss.

\section{Acknowledgments}

We thank the members of our working group for their participation in the sensory analyses.
Chantraine, J.-M., Dhénin, J.-M., and Moretti, C. (2009). Chemical variability of rosewood (Aniba rosaeodora Ducke) essential oil in french guiana. J. Essent. Oil Res. 21, 486-495. doi: 10.1080/10412905.2009.9700225

Chin, Y. W., Chai, H. B., Keller, W. J., and Kinghorn, A. D. (2008). Lignans and other constituents of the fruits of Euterpe oleracea (Acai) with antioxidant and cytoprotective activities. J. Agric. Food Chem. 56, 7759-7764. doi: 10.1021/jf801792n

Czerny, M., Brueckner, R., Kirchhoff, E., Schmitt, R., and Buettner, A. (2011). The influence of molecular structure on odor qualities and odor detection thresholds of volatile alkylated phenols. Chem. Senses 36, 539-553. doi: 10.1093/chemse/bjr009

Czerny, M., Christlbauer, M., Christlbauer, M., Fischer, A., Granvogl, M., Hammer, M., et al. (2008). Re-investigation on odour thresholds of key food aroma compounds and development of an aroma language based on odour qualities of defined aqueous odorant solutions. Eur. Food Res. Technol. 228, 265-273. doi: 10.1007/s00217-008-0931-x

d'Acampora Zellner, B., Casilli, A., Dugo, P., Dugo, G., and Mondello, L. (2007). Odour fingerprint acquisition by means of comprehensive two-dimensional gas chromatography-olfactometry and comprehensive two-dimensional gas 
chromatography/mass spectrometry. J. Chromatogr. A 1141, 279-286. doi: 10.1016/j.chroma.2006.12.035

Field, T., Field, T., Cullen, C., Largie, S., Diego, M., Schanberg, S., et al. (2008). Lavender bath oil reduces stress and crying and enhances sleep in very young infants. Early Hum. Dev. 84, 399-401. doi: 10.1016/j.earlhumdev.2007. 10.008

Friedland, K., and Harteneck, C. (2015). "Spices and odorants as TRP channel activators - smell, taste, chemesthesis and beyond," in Springer Handbook of Odor, ed A. Buettner (Berlin; Heidelberg: Springer-Verlag).

Goel, N., Kim, H., and Lao, R. P. (2005). An olfactory stimulus modifies nighttime sleep in young men and women. Chronobiol. Int. 22, 889-904. doi: $10.1080 / 07420520500263276$

Hasegawa, T. Co., Ltd. (1983). 2,6-Dimethyl-2,7-Octadiene-1,6-Diol. Japan patent application Copyright (C) 2015 American Chemical Society (ACS). All Rights Reserved.

Hudson, R. (1996). The value of lavender for rest and activity in the elderly patient. Complement. Ther. Med. 4, 52-57. doi: 10.1016/S0965-2299(96)80057-4

Kako, H., Fukumoto, S., Kobayashi, Y., and Yokogoshi, H. (2008). Effects of direct exposure of green odour components on dopamine release from rat brain striatal slices and PC12 cells. Brain Res. Bull. 75, 706-712. doi: 10.1016/j.brainresbull.2007.11.016

Kessler, A., Sahin-Nadeem, H., Lummis, S. C., Weigel, I., Pischetsrieder, M., Buettner, A., et al. (2014). GABA(A) receptor modulation by terpenoids from Sideritis extracts. Mol. Nutr. Food Res. 58, 851-862. doi: 10.1002/mnfr.201300420

Kessler, A., Villmann, C., Sahin-Nadeem, H., Pischetsrieder, M., and Buettner, A. (2012). GABAA receptor modulation by the volatile fractions of Sideritis species used as 'Greek' or 'Turkish' mountain tea. Flavour Fragr. J. 27, 297-303. doi: 10.1002/ffj.3099

Kiecolt-Glaser, J. K., Graham, J. E., Malarkey, W. B., Porter, K., Lemeshow, S., and Glaser, R. (2008). Response to Letter to the Editor regarding "Olfactory influences on mood and autonomic, endocrine, and immune function". Psychoneuroendocrinology 33, 1303. doi: 10.1016/j.psyneuen.2008.07.001

King, A. J., and Dickinson, J. R. (2003). Biotransformation of hop aroma terpenoids by ale and lager yeasts. FEMS Yeast Res. 3, 53-62. doi: 10.1111/j.15671364.2003.tb00138.x

Kreck, M., Püschel, S., Wüst, M., and Mosandl, A. (2003). Biogenetic studies in Syringa vulgaris L.: synthesis and bioconversion of deuterium-labeled precursors into lilac aldehydes and lilac alcohols. J. Agric. Food Chem. 51, 463-469. doi: 10.1021/jf020845p

Kremer, D., Dunkić, V., Ruščić, M., Matevski, V., Ballian, D., Bogunić, F., et al. (2014). Micromorphological traits and essential oil contents of Micromeria kerneri Murb. and M.juliana (L.) Benth. (Lamiaceae). Phytochemistry (Elsevier) 98, 128-136. doi: 10.1016/j.phytochem.2013.12.009

Lahlou, M. (2004). Essential oils and fragrance compounds: bioactivity and mechanisms of action. Flavour Fragr. J. 19, 159-165. doi: 10.1002/ffj.1288

Liu, H.-X., Chen, X.-H., and Huang, C.-S. (2003). Facile and efficient syntheses of $( \pm)$-(E)-2,6-dimethyl-6-hydroxy-2,7-octadienoic acid and its methyl ester. Chem. Res. Chin. Univ. 19, 425-427.

Luan, F., Mosandl, A., Degenhardt, A., Gubesch, M., and Wüst, M. (2006). Metabolism of linalool and substrate analogs in grape berry mesocarp of Vitis vinifera L. cv. Morio Muscat: demonstration of stereoselective oxygenation and glycosylation. Anal. Chim. Acta 563, 353-364. doi: 10.1016/j.aca.2006. 01.001

Matsubara, Y., Sawabe, A., Iba, H., and Iizuka, Y. (1990). Structure of terpenoid glycosides in the leaf of hinoki (Chamaecyparies obtusa Sieb. et Zucc.). Agric. Biol. Chem. 54, 555-556. doi: 10.1271/bbb1961.54.555

Miguel, M. G., Dandlen, S., Figueiredo, A. C., Barroso, J. G., Pedro, L. G., Duarte, A., et al. (2008). Essential oils of flowers of Citrus sinensis and
Citrus clementina cultivated in Algarve, Portugal. Acta Hortic. 773, 89-94. doi: 10.17660/actahortic.2008.773.12

Mookherjee, B. D., and Trenkle, R. W. (1973). Isolation, identification, and biogenesis of bifunctional compounds in lavandin oil. J. Agric. Food Chem. 21, 298-302. doi: 10.1021/jf60186a011

Omori, H., Nakahara, K., and Umano, K. (2011). Characterization of aroma compounds in the peel extract of Jabara (Citrus jabara Hort. ex Tanaka). Flavour Fragr. J. 26, 396-402. doi: 10.1002/ffj.2066

Ozek, T., Tabanca, N., Demirci, F., Wedge, D. E., and Baser, K. H. C. (2010). Enantiomeric distribution of some linalool containing essential oils and their biological activities. Rec. Nat. Prod. 4, 180-192.

Pinnick, H. W., Bal, B. S., and Childers, Jr. W. E. (1981). Oxidation of $\alpha$, $\beta$-un saturated aldehydes. Tetrahedron 37, 2091-2096. doi: 10.1016/S00404020(01)97963-3

Renganathan, V., and Madyastha, K. M. (1983). Linalyl Acetate Is Metabolized by Pseudomonas incognita with the Acetoxy Group Intact. Appl. Environ. Microbiol. 45, 6-15.

Stashenko, E. E., and Martínez, J. R. (2008). Sampling flower scent for chromatographic analysis. J. Sep. Sci. 31, 2022-2031. doi: $10.1002 /$ jssc. 200800151

Strauss, C. R., Wilson, B., and Williams, P. J. (1988). Novel monoterpene diols and diol glycosides in Vitis vinifera grapes. J. Agric. Food Chem. 36, 569-573. doi: 10.1021/jf00081a041

Tasev, T., Toléva, P., and Balabanova, V. (1969). [Neurophysical effect of Bulgarian essential oils from rose, lavender and geranium]. Folia Med. (Plovdiv). 11, 307-317.

Tsagkli, A., Hancianu, M., Aprotosoaie, C., Cioanca, O., and Tzakou, O. (2012). Volatile constituents of Romanian coriander fruit. Rec. Nat. Prod. 6, 156-160.

Uchiyama, T., Miyase, T., Ueno, A., and Usmanghani, K. (1989). Terpenic glycosides from Pluchea indica. Phytochemistry 28, 3369-3372. doi: 10.1016/0031-9422(89)80349-8

Ullrich, F., and Grosch, W. (1987). Identification of the most intense volatile flavour compounds formed during autoxidation of linoleic acid. Zeitschrift Lebensmittel-Untersuchung Forschung 184, 277-282. doi: 10.1007/BF01027663

Van Den Dool, H., and Kratz, P. D. (1963). A generalization of the retention index system incliding linear temperature programmed gas-liquid partitionchromatography. J. Chromatogr. 11, 463-471. doi: 10.1016/S00219673(01)80947-X

Van Dort, H. M., Jagers, P. P., Ter Heide, R., and Van Der Weerdt, A. J. A. (1993). Narcissus trevithian and Narcissus geranium: analysis and synthesis of compounds. J. Agric. Food Chem. 41, 2063-2075. doi: 10.1021/jf00035a047

Wakayama, S., Namba, S., Hosoi, K., and Ohno, M. (1973). The synthesis and the absolute configurations of lilac alcohols, new naturally occurring odorous ingredients of lilac flower. Bull. Chem. Soc. Jpn. 46, 3183-3187. doi: $10.1246 /$ bcsj. 46.3183

Yahagi, T., Daikonya, A., and Kitanaka, S. (2012). Flavonol acylglycosides from flower of Albizia julibrissin and their inhibitory effects on lipid accumulation in 3T3-L1 cells. Chem. Pharm. Bull. (Tokyo) 60, 129-136. doi: 10.1248/cpb.60.129

Conflict of Interest Statement: The authors declare that the research was conducted in the absence of any commercial or financial relationships that could be construed as a potential conflict of interest.

Copyright (c) 2015 Elsharif, Banerjee and Buettner. This is an open-access article distributed under the terms of the Creative Commons Attribution License (CC BY). The use, distribution or reproduction in other forums is permitted, provided the original author(s) or licensor are credited and that the original publication in this journal is cited, in accordance with accepted academic practice. No use, distribution or reproduction is permitted which does not comply with these terms. 